DOI: 10.20472/EFC.2020.013.004

EMIL EXENBERGER

Technical University of Košice, Slovakia

MICHAELA KAVČÁKOVÁ

Technical University of Košice, Slovakia

\title{
EVALUATION OF FINANCIAL HEALTH OF COMPANIES THROUGH DATA ENVELOPMENT ANALYSIS: SELECTION OF VARIABLES FOR THE DEA MODEL IN R
}

\begin{abstract}
:
Existing companies need to continually adapt to changing market conditions. The market situation may change, say, from day to day, as in 2008, when the Great Depression broke out, or as is currently the case during the COVID-19 pandemic. For this reason, companies need to monitor their financial health and be able to cope with such unpredictable situations. The aim of this paper is to provide a detailed guide to selecting appropriate financial indicators for the Data Envelopment Analysis model that can be used to evaluate the financial health of companies. Specifically, we use the Mann-Whitney test for indicators of IT companies in Slovakia during 2012-2017. The result is a process of selecting variables to evaluate the financial health of companies through the DEA model, applicable to both business practice and academia.
\end{abstract}

\section{Keywords:}

Data Envelopment Analysis, Mann-Whitney test, financial health, multicolinearity, financial indicators

JEL Classification: C14, C88, M21 


\section{Introduction}

The aim of evaluating a company's financial health is to identify its financial problems in time, which could lead to its bankruptcy. The process of predicting bankruptcy is important not only for the owners and managers of the company, but also for its investors or creditors, as well as borrowing institutions. According to (Chaudhuri and Ghosh 2017) bankruptcy can be considered as the state where the firm is not able to satisfy the debts and requests of the court of law to restructure its debts or liquidate its assets. A number of methods are used to evaluate the financial health of companies, and thus the identification of bankruptcy, such as Zmijewski's X-score, Altman's Z-score, Beaver's model, Quick test, IN indices, etc. However, these models are out of date in their original forms because they were created in the market conditions of the 20th century. For this reason, these models are being modified to the current market conditions or the possibility of using alternative methods such as neural networks or Data Envelopment Analysis (DEA) is being explored.

When using a DEA model, it is important to select the correct sample of companies and variables that enter to the model. In evaluating the financial health of the company, these variables are represented by financial indicators of surveyed companies whose selection is based on a specific procedure that divided them into inputs and outputs of the company.

In this paper we provide a detailed guide to selecting appropriate financial indicators for the Data Envelopment Analysis model that can be used to evaluate the financial health of companies.

\section{Literature preview}

Smith and Winakor (Smith and Winakor 1935) in 1935 and Mervin (Merwin 1942) in 1942 were the first who evaluate the financial health of companies after the outbreak of the so-called Great Depression in the 1930s. These authors laid the foundations for identifying corporate bankruptcy, and since then a number of models have emerged that Kotulič et al. (Kotulič, Király, and Rajčániová 2007) divide into 3 categories:

1. one-dimensional discriminatory analysis;

2. multidimensional discriminatory analysis;

3. scoring methods.

One-dimensional analysis is a mathematical-statistical method, which predicts the financial distress of a company using a single indicator. The best known representatives of this group of methods are (Beaver 1966; Zmijewski 1984; Deakin 1972; Ohlson 1980). Beaver's work is considered as one of the classical works in bankruptcy prediction. He categorized the ratios into 6 groups consisting of 30 ratios. His sample consisted of 79 pairs of bankrupt and non-bankrupt companies. As the best discriminators were considered the working capital funds flow/total assets and net income/total assets. Beaver's model correctly identified about $90 \%$ and $88 \%$ of the companies' cases. From this group of models, however, the most commonly used is so-called Zmijewski X-score. Zmijewski used 40 bankrupt and 800 healthy industrial companies' data for the period 1972-1978 and constructed so-called X-score model by using ROA, leverage, and liquidity ratios. Zmijewski considers a breakpoint for probability of bankruptcy of 0.5 . This model has been used in studies of many authors who have compared it with other models used to evaluate the financial health of companies (Grice Jr and Dugan 2003; Yuliastary and Wirakusuma 2014; Husein and Pambekti 2015; Manalu, Octavianus, and Kalmadara 2017).

Multidimensional discriminatory analysis is also a mathematical-statistical method which predicts financial distress using a set of multiple indicators, with different weights assigned to these indicators. This group of models is used to evaluate a phenomenon that determines several factors with different intensities. Their role is to forecast the financial situation and with reasonable confidence, to classify the company either in a group of financially health companies or in a group of companies in financial distress. In addition, they are also used to compare the situation between companies. This group of models is one of the most commonly used in practice and their best known representative is Altman (Altman 1968) with his Z-score. This test is based on empirical data on companies in financial distress in the last 5 years before bankruptcy and data on prosperous companies for the same period. He then used a multidimensional discriminatory analysis to determine the indicators that characterize the current financial situation of companies and their development. The essence of this analysis is to find a linear combination of indicators that best distinguish companies from bankruptcy and prosperity. Altman used 5 financial indicators to create his equation of Z-score, which many authors have modified it or simply used in their papers (Grice and Ingram 2001; Eidleman 1995; Anjum 2012; Calandro 2007; Chouhan, Chandra, and Goswami 2014; Almamy, Aston, and Ngwa 2016; Ko, Fujita, and Li 2017; Samarakoon and Hasan 2003; Thai et al. 2014; Alexakis 2008; Mohammed 2016). 
Scoring methods predicts the financial development of the company using scales, which are usually determined by expert methods. Known models from this group of methods are Kralick's Quick test or Taffler's model. In 1990, Kralicek (Kralicek 1993) proposed the so-called Quick test, used mainly in Europe. It is a kind of transition between one-dimensional and multidimensional models. From each important area of the analysis, such as stability, liquidity, profitability and profit, he used one selected indicator and created a point scale. This type of model was used in studies worldwide (Vrbka and Rowland 2019; Schönfeld, Kuděj, and Smrčka 2018; Plandor and Landryová 2012; Kuběnka 2016; Polo and Caca 2014) or in Slovakia (Šofranková, n.d.).

Data Envelopment Analysis (DEA) is used to evaluate the technical efficiency of homogeneous units (Decision Making Units - DMU). DEA is a non-parametric method which belongs to a group of mathematical methods based on linear programming. This method aims to divide the surveyed objects into efficient and ineffective according to the size of inputs consumed and the number of outputs. DEA compares these objects to the best one. The basis of DEA models is the so-called production-possibility frontier that is made up of all acceptable combinations of inputs and outputs. This frontier is determined by the production possibility curve, which determines whether or not the investigated unit is effective. The unit is effective if it lies at the production possibility curve. If it does not lie on this border, it is inefficient, and it is necessary to adjust the size of its inputs or outputs. In recent years, many authors (Paradi, Asmild, and Simak 2004; Feruś 2010; Sueyoshi and Goto 2011; Mendelová and Bielikova 2017; Xin, Hoe, and Siew 2019; Horváthová, Mokrišová, and Vrábliková 2019) have been interested in using DEA as an alternative method in evaluating the financial health of companies, because the above-mentioned traditional models are obsolete as they originated in the last century and do not reflect the current market situation.

When selecting inputs to the DEA model, which will be used to assess the financial health of companies, non-parametric tests can be used, which divide a group of indicators into those whose high values are typical for companies in financial health or bankruptcy. Examples of such tests are the Li test (Li, Maasoumi, and Racine 2009) or the Mann Whitney U test (Mann and Whitney 1947), which can be used in various areas of life such as medicine (Kühnast and Neuhäuser 2008; Okeh 2009; Neely et al. 2003), botany (Bogdanov et al. 2007; Simmonds et al. 2000), veterinary medicine (Meurs et al. 1998; Hauptman, Walshaw, and Olivier 1997) or in financial sphere (LeCornu et al. 1996; O'Neill et al. 2006; Ulum, Rizqiyah, and Jati 2016; Büyüksalvarci and Abdioglu 2010; Omoke et al. 2015).

In the following parts of the paper, we will focus on developing a detailed guide to selecting appropriate financial indicators for the Data Envelopment Analysis model that can be used to evaluate the financial health of companies.

\section{Research method}

When working out the literature review, we did not meet a source that would describe the procedure for selecting indicators that should represent inputs to the DEA method in detail. Therefore, the aim of this work will be to provide a detailed guide to selecting appropriate financial indicators for the Data Envelopment Analysis model that can be used to evaluate the financial health of companies. We will run the whole algorithm in the program $\mathrm{R}$, which is the language and environment for statistical computing and graphics (R Core Team 1993).

The data consist of 27 financial indicators calculated values of companies in the years 2013 to 2017. We obtained these data from the FinStat internet portal. For the correct use of the DEA method, it is necessary to produce homogeneous products for the tested companies, so in the selection of test data we will select companies from one industry. As an industry, we chose "Information Technology" in the Slovak Republic because the IT industry is currently one of the fastest growing industries. In order to increase the probability of selecting such indicators that will sufficiently represent the financial situation of the company, it is important that the number of monitored indicators are as large as possible.

The first step will be to add the value of equity of next year (ENY), which will represent the value of equity of the monitored company in the next year. For example, to the calculated values of the indicators of company $X$ in 2013 , we add the value of equity, which the company reported in the year 2014. Based on this value, we then determine the level of financial health of the company, which should be predicted by DEA model. If the value of ENY in year $n+1$ is greater than 0 , then the DEA model should predict the financial health of the selected company in year $n$ as a "financial healthy" company; if the value of ENY in year $n+1$ is less than 0 , then the DEA method should predict the financial health of the selected company in year $n$ as a "financial distress" company.

The next step in our proposed algorithm in the selection of input indicators to the DEA method will be the removal of multicollinearity between the indicators in the dataset. The dependent variable will be the value of ENY and the explanatory variables will be 27 financial indicators. In the R environment 
we use the command $m c=\operatorname{lm}(E N Y \sim$.,Data) (Chambers and Hastie 1992; Wilkinson and Rogers 1973) to calculate the partial linear regressions and use the function vif $(m c)$ to calculate the variance inflation factor for each indicator. If a financial indicator has a value of variance inflation factor $>10$, it indicates the presence of multicollinearity, so we remove such indicators from the dataset.

After removing multicollinearity, we need to identify financial indicators within which the values differ statistically significantly between financial healthy and financial distress companies. For this we can use the Li test (consistent integrated squared difference test) or the Mann Whitney $U$ test. In the final part, we will use the proposed algorithm for selecting inputs to the DEA model 2 times: once using the Li test and the second time using the Mann Whitney $U$ test. We compile DEA models for both input selections and compare the successes of these models. Based on the resulting comparison, we will select the test that will lead to a more successful DEA model to select the inputs of the DEA model.

Using the Li test (consistent integrated squared difference test) (Li, Maasoumi, and Racine 2009), we test the null hypothesis: "There are not significant differences in the jiont distribution within the tested financial indicator between financial healthy and financial distress companies". If we perform the test in the $\mathrm{R}$ environment using the command:

npdeneqtest (healthy_table, distress_table,boot.num $=99$ )

We will perform the given test for each indicator separately. The healthy_table and distress_table tables will have one column, which will represent exactly one analyzed financial indicator. The rows of these tables will contain the values of the financial indicators of companies, which will be divided according to the value of ENY into financial healthy and financial distress companies. The value boot. num represents an integer value specifying the number of bootstrap replications to use (Racine 2020). If the tested indicator within the Li test shows a $p$-value $<0.001$, then we reject $\mathrm{H} 0$ and accept the alternative hypothesis $\mathrm{H} 1$ : "There are significant differences in the jiont distribution within the tested financial indicator between financial healthy and financial distress companies". We will exclude indicators for which we do not reject $\mathrm{HO}$ from our dataset.

Using the Mann Whitney U test (also known as the Wilcoxon test) (Mann and Whitney 1947; Bauer 1972; Hollander, Wolfe, and Chicken 2013), we test the null hypothesis: "There is no difference within the tested financial indicator between financial healthy and financial distress companies". Mann Whitney $\mathrm{U}$ test in the $\mathrm{R}$ environment using the command:

wilcox.test (fin_indicator $\sim$ healthy_distress,data)

The fin_indicator parameter represents a column in the data table in which the financial indicator is tested; The healthy_distress parameter represents a column in the data table that indicates whether it is a financial healthy or financial distress company. If the tested indicator shows a $p-v a l u e<0.05$ within the Mann Whitney $\mathrm{U}$ test, then we reject $\mathrm{HO}$ and accept the alternative hypothesis $\mathrm{H} 1$ : "There is a difference within the tested financial indicator between financial healthy and financial distress companies". We will exclude indicators for which we do not reject $\mathrm{HO}$ from our dataset.

After performing the Li test or Mann Whitney $U$ test, we will remove companies with extreme values of financial indicators especially for financial healthy and financial distress companies. First, we divide the original data table into 2 tables: healthy_companies and distress_companies. We will then remove the extreme values from these tables separately for all financial indicators. In the $\mathrm{R}$ environment, we identify outliers using the command:

boxplot(healthy_companies \$ fin_indicator)\$out.

To identify which of the indicators represent inputs and which outputs to the DEA method, we display boxplots and calculate the arithmetic averages of individual indicators separately for financial healthy and financial distress companies. Then, we compare the averages within one indicator. If the arithmetic average of the monitored indicator will be higher within financial healthy companies than within distress companies, then we identify the given indicator as an input within the DEA method; if lower, we identify it as output under the DEA method. Subsequently, we will create the tables inputs_table and outputs_table, in which the indicators will be sorted on the basis of the performed analysis.

After identifying the inputs and outputs, we perform the DEA method separately for the procedure involving the use of $\mathrm{Li}$ test and Mann Whitney $U$ test and compare the successes of these models determined by the arithmetic mean of $\boldsymbol{I}_{\boldsymbol{C} C}$ (Index of Correct Classification) (Mendelová and Bielikova 2017) for each of the analyzed years, which is calculated as:

$$
I_{C C}=\frac{n_{A}+n_{F}}{n}
$$

where: 
- $n_{A}$ is number of companies in financial distress included in the financial distress zone,

- $n_{F}$ is number of companies in financial health included in the financial health zone,

- $\quad n$ is total number of companies.

We have decided that the SBM model for the VRS condition (Tone 2001) will be applied to quantify the distances of companies from the production possibility curve because it is not necessary to select the input or output orientation of the model.

To preserve the dimensions of the data, each year we selected 100 financial healthy and distress companies as input to the DEA method. We execute the DEA model in the R environment using the commands included in the package deaR (Tone 2001):

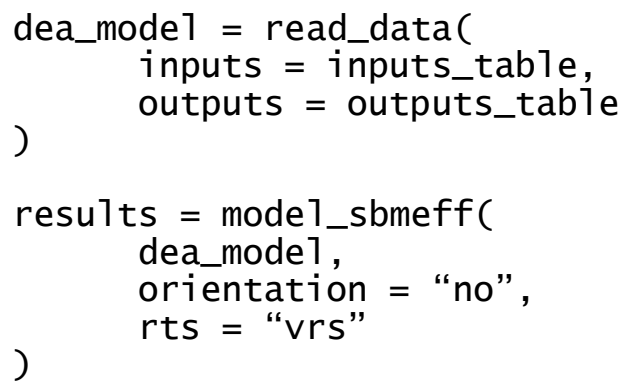

The orientation parameter represents a non-priented DEA model and the rts parameter determining the type of returns to scale (Suarez 2020). Based on the comparison of the success of DEA models, we will subsequently recommend the use of the Li test or the Mann Whitney $U$ test in our proposed procedure for selecting indicators that should represent inputs to the DEA method.

\section{Results and discussion}

To test the algorithm for selecting suitable indicators as inputs to the DEA method, we used the obtained data on 27 calculated financial indicators for 1,551 companies in the "Information Technology" sector in the years 2013 to 2017 . After calculating the equity of the next year (ENY) for each of companies, we removed multicollinearity from the data, while a total of 16 financial indicators were removed from the data. The next step was to identify those indicators within which the values differed statistically significantly between financial healthy and financial distress companies. Since we used both the Li test and the Mann Whitney $U$ test for this identification, the result part of this work is further divided into 2 subchapters, each representing the use of just one of these tests.

\subsection{Li test}

Using the Li test, we identified among the eleven financial indicators those, which values statistically significantly differ between financial healthy and financial distress companies.

Table 1: Li test - results

\begin{tabular}{|c|c|}
\hline financial indicator & Li test $p$-value \\
\hline net debt & $<2.22 \mathrm{E}-16^{* * *}$ \\
\hline gross margin & 0.10101 \\
\hline liabilities / EBITDA & $<2.22 \mathrm{E}-16^{* * *}$ \\
\hline total insolvency & $0.01010^{*}$ \\
\hline return on long-term capital (EBIT) & $<2.22 \mathrm{E}-16^{* * *}$ \\
\hline repayment period of liabilities & $<2.22 \mathrm{E}-16^{* * *}$ \\
\hline $\begin{array}{l}\text { repayment period of liabilities in relation to } \\
\text { sales }\end{array}$ & $<2.22 \mathrm{E}-16^{* * *}$ \\
\hline $\begin{array}{l}\text { repayment period of liabilities of trade } \\
\text { payables }\end{array}$ & 0.66667 \\
\hline effective tax rate & $<2.22 \mathrm{E}-16^{* * *}$ \\
\hline $\begin{array}{l}\text { coverage of personnel costs and } \\
\text { depreciation }\end{array}$ & $<2.22 \mathrm{E}-16^{\star * *}$ \\
\hline surcharge & 0.12121 \\
\hline
\end{tabular}

*** Significant at $p<0.001 ;{ }^{* *}$ Significant at $p<0.01 ;{ }^{*}$ Significant at $p<0.05$ 
Source: Authors' own calculations.

The results of the Li test for each of the indicators are shown in Table 1. We considered financial indicator as suitable, if $p$-value $<0.001$. The following 7 financial indicators are suitable according to the Li test:

- net debt;

- $\quad$ liabilities / EBITDA (earnings before interest, taxes, depreciation and amortization);

- $\quad$ return on long-term capital (EBIT - earnings before interest and taxes);

- repayment period of liabilities;

- $\quad$ repayment period of liabilities in relation to sales;

- $\quad$ effective tax rate;

- coverage of personnel costs and depreciation.

Subsequently, we removed companies with extreme values of financial indicators, especially for financial healthy and financial distress companies. This removed 800 companies from the dataset, leaving 751.

Table 2: Li test - means of financial indicators

\begin{tabular}{|c|c|c|c|}
\hline financial indicator & $\begin{array}{r}\text { mean - } \\
\text { fin. healthy }\end{array}$ & $\begin{array}{r}\text { mean - } \\
\text { fin. distress }\end{array}$ & $\begin{array}{l}\text { DEA input/ } \\
\text { DEA output }\end{array}$ \\
\hline net debt & -264083.90 & -36013.48 & output \\
\hline liabilities / EBITDA & 3.14 & 8.11 & output \\
\hline return on long-term capital (EBIT) & 0.41 & 0.13 & input \\
\hline repayment period of liabilities & 161.34 & 181.22 & output \\
\hline $\begin{array}{l}\text { repayment period of liabilities in relation to } \\
\text { sales }\end{array}$ & 70.34 & 79.91 & output \\
\hline effective tax rate & 0.25 & 0.20 & input \\
\hline $\begin{array}{l}\text { coverage of personnel costs and } \\
\text { depreciation }\end{array}$ & 1.29 & 1.04 & input \\
\hline
\end{tabular}

Source: Authors' own calculations.

Based on the calculated arithmetic means of financial ratios separately for financial healthy and financial distress companies, we divided the remaining 7 financial ratios into inputs and outputs to the DEA method, as described in the previous chapter and shown in Table 2. Then we used the resulting distribution of financial indicators in compiling DEA model for each of the monitored years.

Table 3: Li test - DEA Index of Correct Classification

\begin{tabular}{rrrrrr}
\hline & $\mathbf{2 0 1 3}$ & $\mathbf{2 0 1 4}$ & $\mathbf{2 0 1 5}$ & $\mathbf{2 0 1 6}$ & $\mathbf{2 0 1 7}$ \\
\hline Icc & 0.7455 & 0.7364 & 0.7273 & 0.7818 & 0.8182 \\
\hline
\end{tabular}

Source: Authors' own calculations.

Table 3 shows the $I_{C C}$ values of DEA models in the individual years. The arithmetic mean of these values is 0.76184 and represents the average success of the DEA model using the Li test.

In the next subchapter, we perform the same procedure using the Mann Whitney $\mathrm{U}$ test.

\subsection{Mann Whitney U test}

We repeated the methodological procedure in which the Li test was available, with the difference that we used the Mann Whitney $U$ test to identify financial indicators which values were statistically significantly different between financial healthy and financial distress companies. 
Table 4: Mann Whitney U test - results

\begin{tabular}{lr}
\hline financial indicator & $\begin{array}{r}\text { Mann } \\
\text { Whitney U } \\
\text { test - p-value }\end{array}$ \\
\hline net debt & $4.18 \mathrm{E}-09^{\star * *}$ \\
gross margin & $9.33 \mathrm{E}-01$ \\
liabilities / EBITDA & $1.02 \mathrm{E}-01$ \\
total insolvency & $1.75 \mathrm{E}-05^{\star * *}$ \\
return on long-term capital (EBIT) & $2.99 \mathrm{E}-08^{\star * *}$ \\
repayment period of liabilities & $6.79 \mathrm{E}-03^{\star *}$ \\
repayment period of liabilities in relation & $1.37 \mathrm{E}-03^{\star *}$ \\
to sales & $1.48 \mathrm{E}-01$ \\
repayment period of liabilities of trade & \\
payables & \\
effective tax rate & $3.42 \mathrm{E}-08^{\star * *}$ \\
coverage of personnel costs and & $4.48 \mathrm{E}-12^{\star * *}$ \\
depreciation & \\
surcharge & $7.43 \mathrm{E}-01$ \\
\hline
\end{tabular}

$\overline{\star \star \star}$ Significant at $p<0.001 ;{ }^{* \star}$ Significant at $p<0.01 ;{ }^{*}$ Significant at $p<0.05$

Source: Authors' own calculations.

The results of the Mann Whitney $U$ test for each of the indicators are shown in Table 4 . We considered indicator as suitable, if $p$-value $<0.05$. The following 7 financial indicators are suitable according to the Mann Whitney U test:

- net debt;

- total insolvency;

- $\quad$ return on long-term capital (EBIT - earnings before interest and taxes);

- $\quad$ repayment period of liabilities;

- $\quad$ repayment period of liabilities in relation to sales;

- effective tax rate;

- coverage of personnel costs and depreciation.

The indicators selected using the Li test and the Mann Whitney $U$ test differed in only one indicator, namely liabilities/EBITDA (for the Li test) and total insolvency (for the Mann Whitney U test).

Subsequently, we removed companies with extreme values of financial indicators, especially for financial healthy and financial distress companies. This removed 818 companies from the dataset, leaving 733.

Table 5: Mann Whitney $U$ test - means of financial indicators

\begin{tabular}{lrrr}
\hline financial indicator & $\begin{array}{r}\text { mean - } \\
\text { fin. healthy }\end{array}$ & $\begin{array}{r}\text { mean - } \\
\text { fin. distress }\end{array}$ & $\begin{array}{r}\text { DEA input/ } \\
\text { DEA output }\end{array}$ \\
\hline net debt & -255652.25 & -47589.68 & output \\
total insolvency & 0.91 & 1.30 & output \\
return on long-term capital (EBIT) & 0.38 & 0.12 & input \\
repayment period of liabilities & 163.46 & 182.10 & output \\
repayment period of liabilities in relation to sales & 73.32 & 85.08 & output \\
effective tax rate & 0.25 & 0.18 & input \\
coverage of personnel costs and depreciation & 1.27 & 1.03 & input \\
\hline
\end{tabular}

Source: Authors' own calculations. 
Based on the calculated arithmetic means of financial indicators separately for financial healthy and financial distress companies, we divided the remaining 7 financial indicators into inputs and outputs to the DEA method as described in the previous chapter and shown in Table 5. We used the resulting distribution of financial indicators in compiling DEA model for each of the monitored years.

Table 6: Mann Whitney U test - DEA Index of Correct Classification

\begin{tabular}{rrrrrr}
\hline & $\mathbf{2 0 1 3}$ & $\mathbf{2 0 1 4}$ & $\mathbf{2 0 1 5}$ & $\mathbf{2 0 1 6}$ & $\mathbf{2 0 1 7}$ \\
\hline $\mathrm{I}_{\mathrm{CC}}$ & 0.7818 & 0.7636 & 0.8182 & 0.8 & 0.7727 \\
\hline
\end{tabular}

Source: Authors' own calculations.

Table 6 shows the $I_{C C}$ values of the DEA models for each year. The arithmetic mean of these values is 0.78726 and represents the average success of the DEA model using the Mann Whitney U test.

Table 7: Comparison of DEA models' $I_{C C}$ based on Mann Whitney $U$ test and Li test

\begin{tabular}{lrrrrr}
\hline & $\mathbf{2 0 1 3}$ & $\mathbf{2 0 1 4}$ & $\mathbf{2 0 1 5}$ & $\mathbf{2 0 1 6}$ & $\mathbf{2 0 1 7}$ \\
\hline Mann Whitney U test - Icc & 0.7818 & 0.7636 & 0.8182 & 0.8 & 0.7727 \\
Li test - Icc & 0.7455 & 0.7364 & 0.7273 & 0.7818 & 0.8182 \\
\hline
\end{tabular}

Source: Authors' own calculations.

Table 7 shows the $I_{C C}$ values calculated for DEA models. When comparing them, we found that in four of the five years, the DEA model was more successful, in which we used the Mann Whitney $U$ test. The average $I_{C C}$ value of the DEA model in which we selected the inputs of the Mann Whitney $U$ test is 0.02542 higher than when using the Li test.

Based on the results, we recommend using the Mann Whitney $U$ test within our proposed algorithm when selecting inputs to the DEA method for assessing the financial health of the company. Due to its elaboration and introduction of the procedure in the programming language $\mathrm{R}$, our proposed algorithm for selecting inputs to the DEA model can be used in any industry without higher costs. We consider the main benefit of the work to be a detailed description of the proposed algorithm and a comparison of the success of DEA models, which differed in the method used in the selection of appropriate financial indicators.

\section{Conclusion}

The main goal of this work was to provide a detailed guide to selecting appropriate financial indicators for the Data Envelopment Analysis model that can be used to evaluate the financial health of companies. We performed the whole algorithm in the programming language $\mathrm{R}$. This programming language is freely available, which allows companies to use this algorithm for free.

As part of our work, we tested our proposed algorithm for the "Information Technology" industry and compared the success of DEA models, which used the Li test and Mann Whitney $U$ test. Based on the results, we recommend the use of the Mann Whitney $U$ test in the selection of financial indicators as inputs to the DEA method, due to its higher overall success.

In the next work we plan to compare the success of financial health prediction of the company DEA model, into which inputs were selected based on the algorithm described in this work with the success of the neural network model, which will predict based on available financial indicators whether the company will be financial healthy or financial distress.

\section{Acknowledgement:}

The research was realized within the national project "Decision Support Systems and Business Intelligence within Network Economy" (Contract No. 1/0201/19) funded by Grant Agency for Science; Ministry of Education, Science, Research and Sport of the Slovak Republic and supported by VEGA project No. 1/0794/18.

\section{References}

Alexakis, Panayotis. 2008. "'Altman Z-Score Model'and Prediction of Business Failures." International 
Journal of Monetary Economics and Finance 1 (4): 329-37.

Almamy, Jeehan, John Aston, and Leonard N Ngwa. 2016. "An Evaluation of Altman's Z-Score Using Cash Flow Ratio to Predict Corporate Failure amid the Recent Financial Crisis: Evidence from the UK." Journal of Corporate Finance 36: 278-85.

Altman, Edward I. 1968. "Financial Ratios, Discriminant Analysis and the Prediction of Corporate Bankruptcy." The Journal of Finance 23 (4): 589-609.

Anjum, Sanobar. 2012. "Business Bankruptcy Prediction Models: A Significant Study of the Altman's ZScore Model." Available at SSRN 2128475.

Bauer, David F. 1972. "Constructing Confidence Sets Using Rank Statistics." Journal of the American Statistical Association 67 (339): 687-90.

Beaver, William H. 1966. "Financial Ratios as Predictors of Failure." Journal of Accounting Research, 71111.

Bogdanov, Stefan, Max Haldimann, Werner Luginbühl, and Peter Gallmann. 2007. "Minerals in Honey: Environmental, Geographical and Botanical Aspects." Journal of Apicultural Research 46 (4): 269 75.

Büyüksalvarci, A, and H Abdioglu. 2010. "Corporate Governance, Financial Ratios and Stock Returns: An Empirical Analysis of Istanbul Stock Exchange (ISE)." International Research Journal of Finance and Economics 57: 70-81.

Calandro, Joseph. 2007. "Considering the Utility of Altman's Z-score as a Strategic Assessment and Performance Management Tool." Strategy \& Leadership.

Chambers, J M, and T J Hastie. 1992. "Linear Models. Chapter 4 of Statistical Models in S." Wadsworth \& Brooks/Cole.

Chaudhuri, Arindam, and Soumya K Ghosh. 2017. Bankruptcy Prediction through Soft Computing Based Deep Learning Technique. Springer.

Chouhan, Vineet, Bibhas Chandra, and Shubham Goswami. 2014. "Predicting Financial Stability of Select BSE Companies Revisiting Altman Z Score." International Letters of Social and Humanistic Sciences 15 (2): 92-105.

Deakin, Edward B. 1972. "A Discriminant Analysis of Predictors of Business Failure." Journal of Accounting Research, 167-79.

Eidleman, Gregory J. 1995. "Z Scores-a Guide to Failure Prediction." The CPA Journal 65 (2): 52.

Feruś, Anna. 2010. "The Application of DEA Method in Evaluating Credit Risk of Companies." Contemporary Economics 4 (4): 107-14.

Grice, John Stephen, and Robert W Ingram. 2001. "Tests of the Generalizability of Altman's Bankruptcy Prediction Model." Journal of Business Research 54 (1): 53-61.

Grice Jr, John Stephen, and Michael T Dugan. 2003. "Re-Estimations of the Zmijewski and Ohlson Bankruptcy Prediction Models." Advances in Accounting 20: 77-93.

Hauptman, J G, R Walshaw, and N B Olivier. 1997. "Evaluation of the Sensitivity and Specificity of Diagnostic Criteria for Sepsis in Dogs." Veterinary Surgery 26 (5): 393-97.

Hollander, Myles, Douglas A Wolfe, and Eric Chicken. 2013. Nonparametric Statistical Methods. Vol. 751. John Wiley \& Sons.

Horváthová, J, M Mokrišová, and M Vrábliková. 2019. "Integration of Balanced Scorecard and Data Envelopment Analysis to Measure and Improve Business Performance." Management Science Letters 9 (9): 1321-40.

Husein, M Fakhri, and Galuh Tri Pambekti. 2015. "Precision of the Models of Altman, Springate, Zmijewski, and Grover for Predicting the Financial Distress." Journal of Economics, Business, \& Accountancy Ventura 17 (3): 405-16.

Ko, Yu-Chien, Hamido Fujita, and Tianrui Li. 2017. "An Evidential Analysis of Altman Z-Score for Financial Predictions: Case Study on Solar Energy Companies." Applied Soft Computing 52: 748-59.

Kotulič, Rastislav, Peter Király, and Miroslava Rajčániová. 2007. Finančná Analýza Podniku. lura Edition. Kralicek, Peter. 1993. "Základy Finančního Hospodaření. Přeložil Josef Spal. Linde, Praha 1993."

Kuběnka, Michal. 2016. "Interconnection between Achieved Level of Return on Equity and Evaluation Scale of the Kralicek' S Model." International Journal of Management Science and Business Administration, Volume 2, Issue: 5. 
Kühnast, Corinna, and Markus Neuhäuser. 2008. "A Note on the Use of the Non-Parametric WilcoxonMann-Whitney Test in the Analysis of Medical Studies." GMS German Medical Science 6.

LeCornu, Mark R, Richard G P McMahon, David M Forsaith, and Anthony M J Stanger. 1996. "The Small Enterprise Financial Objective Function." Journal of Small Business Management 34 (3): 1.

Li, Qi, Esfandiar Maasoumi, and Jeffrey S Racine. 2009. "A Nonparametric Test for Equality of Distributions with Mixed Categorical and Continuous Data." Journal of Econometrics 148 (2): 186200.

Manalu, Sahala, Rony Joyo Negoro Octavianus, and Galuh Safarina Sari Kalmadara. 2017. "Financial Distress Analysis With Altman Z-Score Approach and Zmijewski X-Score On Shipping Service Company." Jurnal Aplikasi Manajemen 15 (4): 677-82.

Mann, Henry B, and Donald R Whitney. 1947. "On a Test of Whether One of Two Random Variables Is Stochastically Larger than the Other." The Annals of Mathematical Statistics, 50-60.

Mendelová, Viera, and Tatiana Bielikova. 2017. "Diagnostikovanie Finančného Zdravia Podnikov Pomocou Metódy DEA: Aplikácia Na Podniky v Slovenskej Republike [Diagnosing of the Corporate Financial Health Using DEA: An Application to Companies in the Slovak Republic]." Politická Ekonomie 2017 (1): 26-44.

Merwin, Charles L. 1942. Financing Small Corporations in Five Manufacturing Industries, 1926-1936. National Bureau of Economic Research, New York.

Meurs, K M, M A Anthony, M Slater, and M W Miller. 1998. "Chronic Trypanosoma Cruzi Infection in Dogs: 11 Cases (1987-1996)." Journal of the American Veterinary Medical Association 213 (4): 497-500.

Mohammed, Shariq. 2016. "Bankruptcy Prediction by Using the Altman Z-Score Model in Oman: A Case Study of Raysut Cement Company SAOG and Its Subsidiaries." Australasian Accounting, Business and Finance Journal 10 (4): 70-80.

Neely, J Gail, James M Hartman, James W Forsen Jr, and Mark S Wallace. 2003. "Tutorials in Clinical Research: VII. Understanding Comparative Statistics (Contrast)-Part B: Application of T-test, Mann-Whitney U, and Chi-Square." The Laryngoscope 113 (10): 1719-25.

O'Neill, Barbara, Aimee Prawitz, Benoit Sorhaindo, Jinhee Kim, and E Thomas Garman. 2006. "Changes in Health, Negative Financial Events, and Financial Distress/Financial Well-Being for Debt Management Program Clients." Journal of Financial Counseling and Planning 17 (2).

Ohlson, James A. 1980. "Financial Ratios and the Probabilistic Prediction of Bankruptcy." Journal of Accounting Research, 109-31.

Okeh, U M. 2009. "Statistical Analysis of the Application of Wilcoxon and Mann-Whitney U Test in Medical Research Studies." Biotechnology and Molecular Biology Reviews 4 (6): 128-31.

Omoke, Victor, Ikechukwu A Diugwu, Obioma R Nwaogbe, Callistus C Ibe, and David A Ekpe. 2015. "Infrastructure Financing and Management: The Impact of Concession on the Operations and Performance of Nigerian Seaports." Journal of Behavioural Economics, Finance, Entrepreneurship, Accounting and Transport 3 (2): 65-70.

Paradi, Joseph C, Mette Asmild, and Paul C Simak. 2004. "Using DEA and Worst Practice DEA in Credit Risk Evaluation." Journal of Productivity Analysis 21 (2): 153-65.

Plandor, David, and Lenka Landryová. 2012. "Bankruptcy and Financial Standing Models Application for SMEs." In The Seventh International Conference on Software Engineering Advances, 161-64. Citeseer.

Polo, Antoneta, and Enkela Caca. 2014. "KRALICEK QUICK TEST--AN ANALYSIS TOOL FOR ECONOMIC UNITS DETERMINATION IN LIABILITY DIFFICULTY." European Scientific Journal 10 (19).

R Core Team. 1993. “About @ Www.R-Project.Org.” https://www.r-project.org/about.html.

Racine, Jeffrey S.; Tristen Hayfield. 2020. "Package ' Np ." https://cran.rproject.org/web/packages/np/np.pdf.

Samarakoon, Lalith P, and Tanweer Hasan. 2003. "Altman's Z-Score Models of Predicting Corporate Distress: Evidence from the Emerging Sri Lankan Stock Market." Journal of the Academy of Finance 1: 119-25.

Schönfeld, Jaroslav, Michal Kuděj, and Luboš Smrčka. 2018. "Financial Health of Enterprises Introducing Safeguard Procedure Based on Bankruptcy Models." Journal of Business Economics and 
Management 19 (5): 692-705.

Simmonds, M S J, J D Manlove, W M Blaney, and B P S Khambay. 2000. "Effect of Botanical Insecticides on the Foraging and Feeding Behavior of the Coccinellid PredatorCryptolaemus Montrouzieri." Phytoparasitica 28 (2): 99.

Smith, R, and A Winakor. 1935. "Changes in Financial Structure of Unsuccessful Industrial Corporations, Bureau of Business Research, Bulletin Number 51." University of Illinois Press, Urbana.

Šofranková, Beáta. n.d. "ANALYSIS OF FINANCIAL HEALTH BY QUICK TEST AT ACCOMMODATION FACILITIES IN SLOVAKIA."

Suarez, Vicente Coll-Serrano; Vicente Bolos; Rafael Benitez. 2020. "Package 'DeaR." 2020.

Sueyoshi, Toshiyuki, and Mika Goto. 2011. "DEA Approach for Unified Efficiency Measurement: Assessment of Japanese Fossil Fuel Power Generation." Energy Economics 33 (2): 292-303.

Thai, Siew Bee, Han Hwa Goh, Boon HengTeh, JiaChian Wong, and Tze San Ong. 2014. "A Revisited of Altman Z-Score Model for Companies Listed in Bursa Malaysia." International Journal of Business and Social Science 5 (12).

Tone, Kaoru. 2001. "A Slacks-Based Measure of Efficiency in Data Envelopment Analysis." European Journal of Operational Research 130 (3): 498-509.

Ulum, Ihyaul, Rizqiyah Rizqiyah, and Ahmad Waluya Jati. 2016. "Intellectual Capital Performance: A Comparative Study between Financial and Non-Financial Industry of Indonesian Biggest Companies." International Journal of Economics and Financial Issues 6 (4): 1436-39.

Vrbka, Jaromír, and Zuzana Rowland. 2019. "Assessing the Financial Health of Companies Engaged in Mining and Extraction Using Methods of Complex Evaluation of Enterprises." In Sustainable Growth and Development of Economic Systems, 321-33. Springer.

Wilkinson, G N, and C E Rogers. 1973. "Symbolic Description of Factorial Models for Analysis of Variance." Journal of the Royal Statistical Society: Series C (Applied Statistics) 22 (3): 392-99.

Xin, Agnes Lai Jing, Lam Weng Hoe, and Lam Weng Siew. 2019. "An Empirical Evaluation on the Credit Risk Efficiency of Financial Institutions in Malaysia with Data Envelopment Analysis Model." In AIP Conference Proceedings, 2138:40023. AIP Publishing LLC.

Yuliastary, Etta Citrawati, and Made Gede Wirakusuma. 2014. "Analisis Financial Distress Dengan Metode Z-Score Altman, Springate, Zmijewski." E-Jurnal Akuntansi, 379-89.

Zmijewski, Mark E. 1984. "Methodological Issues Related to the Estimation of Financial Distress Prediction Models." Journal of Accounting Research, 59-82. 